\title{
PENGARUH TRADISI PEMBERIAN NASI PAPAH TERHADAP BOUNDING ATTACHMENT DAN KESEHATAN PADA BAYI USIA 6-12 BULAN DI DESA SAMBORI KECAMATAN LAMBITU
}

\author{
Supriadin ${ }^{*}$, Wahidah \\ STIKES YahyaBima \\ e-mail: supriadinmyusuf@gmail.com*
}

\begin{abstract}
Introduction: NasiPapah or in Bima language "Ohara mama" which is food that has been spilled or crushed with the mother's mouth which is then given to the baby. Purpose: to know the influence of rice papah tradition on bounding attachment and health in infants aged 6-12 months in Sambori Village Lambitu District Bima Regency. Method: The design of this study uses a qualitative approach to phenomenological studies against 9 participants based on triangulation techniques. Result: This study produced 4 themes namely: 1) strong body endurance 2) strong wthstand hunger 3) fast satiety 4) not fussy. Conclusion: the administration of MP breast milk in infants aged 6-12 months such as rice porridge containing carbohydrates can be given, as long as it remains concerned about hygienes and the number of portions of food given according to the growth of the baby.
\end{abstract}

Keywords: NasiPapah, bounding attachment, health

\begin{abstract}
ABSTRAK
Pendahuluan: NasiPapahataudalambahasaBima

"Ohara mama" yaitumakanan yang telahdipapahataudilumatkandenganmulutibu yang kemudiandiberikankepadabayi.Tujuan: untukmengetahuipengaruhtradisipemberiannasipapahterhadap bounding attachment dankesehatanpadabayiusia 6-12 bulan di DesaSamboriKecamatanLambituKabupatenBima. Metode: Desainpenelitianinimenggunakanpendekatankualitatifstudifenomenologiterhadap 9 partisipanberdasarkantekhniktriangulasi. Hasil: Penelitianinimenghasilkan 4 temayaitu: 1) dayatahantubuhkuat 2) kuatmenahanlapar 3) cepatkenyang 4) tidakrewel. Kesimpulan: pemberian MP ASI padabayiusia 6-12 bulansepertibuburberas yang mengandungkarbohidratboleh di berikan, asalkantetapmemperhatikanhygienesdanjumlahporsimakanan yang di berikansesuaidengntumbuhkembangbayi.
\end{abstract}

Kata kunci: NasiPapah, bounding attachment, kesehatan

\section{PENDAHULUAN}

Cara pemberian makanan pendamping ASI pada Bayi sedikit banyak dipengaruhi oleh tradisi budaya di suatu daerah tertentu. Ada beberapa tradisi budaya yang dilakukan oleh masyarakat dalam memberikan makanan pendamping ASI diantaranya adalah tradisi budaya nasi papah yang masih banyak dilakukan oleh para ibu di beberapa wilayah di Indonesia, diantaranya di kabupaten Bima khususnya Desa Sambori, Propinsi Nusa Tenggara Barat.

Menurut penduduk Kabupaten Bima khususnya masyarakat Desa Sambori, nasi papah mempunyai pengaruh besar pada perkembangan tubuh dan kecerdasan anak dan hal tersebut sudah menjadi budaya atau tradisi yang di turunkan secara turun temurun oleh masyarakat di desa sambori. Nasi papah yaitu nasi yang dilumatkan dengan mulut yang kemudian diberikan kepada bayi dan itu sudah berlangsung secara turun temurun. Seandainya nasi papah diberikan kepada bayi dimana umurnya dibawah 6 bulan yang daya tahan tubuhnya lemah, tidak pernah terbayangkan bahwa banyak virus yang masuk kedalam tubuhnya.

Dampak dari pemberian nasi papah itu mungkin tidak terlihat secara langsung tetapi, seandainya bayi telah tertular maka penyakit tersebut akan bersarang di dalam tubuhnya, hal itulah yang sangat berpengaruh terhadap pertumbuhan serta daya pikirnya. Pemberian nasi papah jelas sangat kurang dari aspek pemenuhan kebutuhan gizi tersebut, dimana biasanya yang dipapah hanya makanan sumber Karbohidrat saja seperti beras atau nasi dan sangat jarang ditambahkan makanan yang lain baik makanan sumber protein maupun vitamin dan mineral. Sehingga akan sulit memenuhi kebutuhan zat gizi bayi. Nasi papah juga dapat menjadi media penyebaran penyakit antara si ibu degan bayi, dimana jika seorang ibu menderita penyakit-penyakit infeksi menular tertentu yang berhubungan dengan gigi dan 
mulut serta pernapasan maka akan sangat mudah untuk ditularkan pada bayinya. Misalnya Tuberculosis. (Rohmin,2016).

Menurut masyarakat desa Sambori dengan memberikan nasi papah akan meningkatkan kedekatan antara ibu dan anak, serta membuat anak menjadi patuh terhadap ibunya, hal ini dapat juga disebut sebagai bounding attachment. Bounding attachment adalah sebuah peningkatan hubungan kasih sayang dengan keterikatan batin antara orang tua dan bayi (pemenuhan emosional dan saling membutuhkan).

Faktor yang mempengaruhi bounding attachment salah satunya dengan pemberian ASI Ekslusif. Dengan dilakukan pemberian ASI secara ekslusif segera setelah bayi lahir akan mengalami kontak kulit dengan ibunya yang menjadikan ibu merasa bangga dan diperlukan, rasa yang dibutuhkan oleh semua manusia. Pemberian Asi secara ekslusif dilakuakn oleh ibu kepada bayi dari umur 0 bulan sampai dengan 6 bulan. Bayi yang berumur 6 bulan keatas akan mulai di berikan makanan pendamping ASI. Pemberian makanan pendamping ASI juga perlu memperhatikan tingkatan umur bayi, dimana semakin besar umurnya maka kebutuhannya juga akan semakin meningkat.

Dari segi kebersihan dan keamanan pangan nasi papah masih perlu dipertanyakan juga, karena anak bisa tertular penyakit yang diderita ibu melalui air liur, sedangkan dari segi kuantitas dan kualitas nilai gizi jelas merugikan si bayi, karena ibu-ibu akan mendapatkan sari makanan sedangkan bayinya akan mendapatkan ampasnya.

Dari Pemaparan diatas, nampak jelas terlihat banyak sekali hal yang perlu kita ketahui secara mendalam tentang tradisi Masyarakat Desa Sambori, sehingga dapat memperluas khasanah keilmuan dan untuk lebih memahami bahwa indonesia mempunyai berbagai budaya dan adat istiadat masing-masing sehingga kita mempunyai bekal untuk manentukan sikap dan jalan apa yang paling tepat untuk menyikapinya.

\section{METODE}

Jenispenelitian yang digunakandalampenelitianiniadalahkualitatifdenganpe ndekatanfenomenologi.

Penelitimelakukanpenelitianiniuntukmendapatkan data mengenaiobjek yang ditelitidenganmenggunakanteknikTriangulasidimanad enganmelakukanpenggabungandariberbagaitekhnikpe ngumpulan data dansumber data yang telahadasepertiwawancaramendalam (in-depth interview), observasi non partisipan, dandokumentasi.

\section{HASIL}

Karakteristikpartisipandalampenelitianiniterdir idari 9 partisipandengankarakteristik 3 partisipanibu, 3 pastispanbidandan 3 partispantokohmasyarakat
Diidentifikasi
4 tema
yang menjelaskanPengaruh Tradisi Pemberian Nasi Papah Terhadap Bounding Attachment Dan Kesehatan Pada Bayi Usia 6-12 Bulan Di Desa Sambori Kecamatan Lambitu KabupatenBimaTemapadapenelitianyaitu 1) dayatahantubuhkuat 2) kuatmenahanlapar 3) cepatkenyang 4) tidakrewel

\section{DayaTahanTubuhKuat}

Alasanpemberiannasipapahdapatmemberikandayataha ntubuh

Beberapaungkapanpartisipan:

tidak gampang hido lokona serta gemuk (P1)

sebagai oha pendamping susu buat ana nami (P2)

dan ana nami tidak cepat menangis kalau sudah di berikan nasi papah dan sarumbuna sehat sehat poda $(P 3)$

memberikan kekuatan dan pertumbuhan yang yang baik (P7)

memberikan kekuatan, badanyabagus (P8)

memberikan kekebalan pada bayi (P9)

\section{KuatMenahanLapar}

Partisipanmengungkapkanbahwadenganpemberiannas ipapahpadabayiUsia 6-12 Bulandapatmenahanlapar

Beberapaungkapanpartisipan:

karena mbeisi nasi papah (oha mama) anaknya kami akan menjadi kuat menahan lapar (P1)

Tidak cepat lapar (P2)

wati ricu hido lokona (P3)

bayinya tidak mudah lapar (P4)

tidak cepat lapar (P5)

tidak cepat lepar katanya (P6)

tidak terlalu cepat lapar (P7)

kekuatan dan tidak mudah lapar (P8)

kuat menahan lapar (P9)

\section{CepatKenyang}

Partisipanmengungkapkanbahwadenganpemberiannas ipapahpadabayiUsia 6-12 Bulandapatcepatkenyang.

Beberapaungkapanpartisipan:

selain itu juga oha ra mama membuat anak kami itu cepat kenyang $(P 1)$

oha ra mama juga sebagai oha pendamping susu buat ana nami sehingga anak nami cepat kenyang $(P 2)$

cepat kenyang (P3)

dapatmemberikakekenyangan cepat(P7)

menjadi sehat, cepatkenyang, tahanlapar (P8)

cepatsekalikenyang (P9)

\section{TidakRewel}

Partisipanmengungkapkanbahwadenganpemberiannas ipapahpadabayiUsia 6-12 Bulandapatcepattidakrewel 
Beberapaungkapanpartisipan:

dan ana nami tidak cepat menangis dan tidak rewel $(P 1)$

jarang nangis dan gak rewel (P2)

tidak gampang nangis dan wati rewel (P3)

anaknya tidak rewel (P4)

selain itu juga ketika anaknya di berikan nasi papah anaknya tidak rewel (P5)

sehinggaanaknyatidakrewelpadasaat diberikannasipapah (P6)

bayi menjadi sehatdantidakrewel (P7)

semakin sehat-sehat Dan anak kami tidakpernahrewel (P8)

bayi menjadi sehatdantidakpernahterlihatrewel (P9).

\section{PEMBAHASAN}

\section{DayaTahanTubuhKuat}

Menurutpeneltiaindokteranakdr. Fatimah

Hidayati, Sp.A (2016) bahwapemberian MPASI padaanakboleh di berikan paling lambat 6 bulandenganbeberapaalasansebagaiberikutMPASI

diberikan pada usia yang tepat, yaitu ketika ASI saja tidak mencukupi kebutuhan nutrisi bayi. IDAI dan WHO merekomendasikan pemberian MPASI selambat-lambatnya usia 6 bulan. Namun pada kondisi tertentu, misalnya kenaikan berat badan (BB) yang kurang baik, Si Kecil dapat mulai diberikan MPASI setelah dievaluasi penyebabnya dan setelah kesiapan makannya dinilai oleh dokter.Tidak ada aturan mengenai makanan apa yang harus diperkenalkan pertama kali. Yang penting diingat adalah penuhi kecukupan nutrisi anak dengan memberikan karbohidrat, protein, dan lemak yang cukup, serta mengenalkan beragam jenis makanan. Tidak ada penundaan jenis protein tertentu (daging, ikan, dan telur boleh diberikan sejak usia 6 bulan).Namuntetapmemperhatikankebersihanpadasaat proses

pemberianpadabayisebabsangatrentangterinfeksimikor ganismelainya

penelitian yang serupa yang di lakukan oleh ESPGHAN (Asosiasi Dokter Anak Khusus Nutrisi dan Pencernaan di eropa ) merekomendasikan pemberian MPASI yang berusia12 minggu, dan tidak lebih lambat dari usia 26 minggu (6 bulan). Pemberian MPASI terlalu dini berisiko menyebabkan infeksi saluran cerna, alergi, dan obesitas. Sedangkan jika terlalu lambat akan menyebabkan kekurangan asupan gizi hingga stunting Oleh karena itu, konsultasikan ke dokter anak untuk menilai apakah Si Kecil sudah boleh mulai diberikan makanan pendamping ASI.

Menu

MPASI

diberikandisarankanmengandungkebutuhannutrisi

yang tidakdapatdipenuhilagioleh ASI,

terutamajumlahenergi, protein, zatbesi, danzinc.

Tidakadasatujenismakanan

dapatmemenuhisemuanya. Olehkarenaitu, berikan
MPASI

yang

bervariasidanmencukupisumberkarbohidrat, protein hewanidannabati, lemak, sertamikronutrien, yaitu vitamin dan mineral. Menu sepertiinidikenaldengan menu lengkap. Kenalkanbuahdansayurdalamjumlahkecildenganmem erhatikanasupandankomposisikarbohidrat, protein, danlemak pada MPASI. Berikanlah MPASI daribahanmakanan yang biasakeluargamakan. Contohnyaikankembung, yang ternyatamemilikikandungan protein yang tidakjauhberbedadari ikan salmon. Dan bahkan, kandunganzatbesidan DHA ikankembunglebihtinggidibandingikan salmon yang cukupfavoritmenjadi menu MPASI. Selainitu, berhatihatilahdenganpanduan MPASI yang banyakberedar, MPASI diberikandenganjumlahdantekstur yang ditingkatkansesuaitahapannya.Keterlambatanpengenal anteksturpadausia bulanberisikomenyebabkanmasalahmakanpadaanak di kemudianhari

\section{KuatMenahanLapar}

Menurut penelitian Dokter anak I Gusti Ayu Nyoman Partiwi alias Tiwi menyarankan agar makanan pendamping air susu ibu (MP ASI) bisa dimulai dengan pemberian karbohidrat. "Banyak yang pikir sebaiknya kasih buah, padahal sebaiknya bayi diberi karbohidrat dulu, asupan yang sebaiknya diperkenalkan kepada bayi dalam tahap MP ASI adalah karbohidrat, protein hewani, protein nabati, sayur lalu terakhir buah. "Buah ada di urutan terakhir karena buah itu banyak serat dan pencernaan bayi susah untuk menerima serat. Karbohidrat yang dapat diberikan kepada bayi bisa berupa beras, atau tepung beras. Bentuk penyajiannya bisa dibuat menjadi bubur susu. Dalam buku Sehat Lezat Olah Saji karya dr Tiwi, tertulis bahwa tepung beras dapat dibuat sendiri. Jika menggunakan tepung beras siap olah, ia menyarankan agar orang tua memilih makanan yang tanpa gula dan sebaiknya diperkaya dengan zat besi. Karbohidrat, berperan penting menambah berat badan bayi. "Memang utamanya kan berat badan bayi tidak boleh menurun, maka harus naik terus, menyarankan agar jangan dulu memberikan karbohidrat dengan serat tinggi seperti kentang atau ubi. "Karena serat susah dicerna bayi di bawah usia 12 bulan. Selanjutnya tidak cuman karbohidrat saja yang dapat di berikan pada bayi 6-12 bulan tetapi MPASI tambahan lainya seperti protein hewani. Bayi boleh mulai dikenalkan dengan daging sapi, hati ayam, ikan. Tiwi sangat menyarankan untuk mengkonsumsi makanan lokal yang ada di daerah masing-masing. Sebab dengan mengkonsumsi protein dapat memberikan kekuatan pada bayi misalnya untuk pertunmuhan ototnya. Setelah itu, bayi boleh mulai diperkenalkan dengan protein nabati seperti kacangkacangan. Lalu pada tahap terakhir adalah perkenalan dengan sayur dan buah. Artinya bisa di simpulkan bahwa Gizi itu tidak bisa dipenuhi hanya dengan ASI. 
ASI hanya dapat menyuplai 400 kalori dan 10 gram protein. Maka MP ASI perlu memenuhi kekurangan 250 kalori dan 6 gram protein yang dibutuhkan anak setiap hari.

\section{CepatKenyang}

Menurutpenelitian yang di lakukanolehogi, E.D. (2016) Agar bayidananakbisakenyangdantumbuhkembangdengan optimal, orang tuaharusmemperhatikan ASI danmakanan yang dikonsumsinya. ASI merupakansatu-satunyamakanan yang mengandungzatgizi yang dibutuhkanuntukpertumbuhanbayiusia $\quad 0-6$ bulan. Namundenganbertambahnyausiabayidantumbuhkemb ang, tidaknya orang tuaharusmemperhatikankekeknyanganpadabayisebabk etikabayikeseringanmerasakankelaparansudahbisa di pastikanbahwabayitersebutakanmengalamikebutuhann utrisisebabbayimemerlukanenergidanzat-zatgizi yang melebihijumlah

ASI.

Bayiharusmendapatmakanantambahan/ pendamping ASI atau yang biasadisebutdengan MPASI.

Makanan pendamping ASI (MP ASI) merupakan makanan peralihan dari ASI ke makanankeluarga yang mengandung zat gizi yang dapat menmpercepat kekenyangan pada bayi sebab perut bayi sudah terisi oleh makanan, MP ASI diberikan pada anak berumur 6-24 bulan untuk memenuhi kebutuhan gizinya selain dari ASI. Peranan makanan tambahan sama sekali bukan untuk menggantikan ASI, melainkan untuk melengkapi ASI. Pengenalan dan pemberian MP-ASI harus dilakukan secara bertahap baik bentuk maupun jumlahnya, sesuai dengan kemampuan pencernaan bayi/anak. Oleh karena itu, untuk mencapai tumbuh kembang optimal, Ibu bisa memberikan ASI pada bayi usia 0-6 bulan. Dan ibu segera mulai mengenalkan pemberian MPASI kepada bayinya yang sudah berusia 6 bulan. Inilah makanan bayi kedua yang menyertai pemberian ASI. Ada beberapa alasan MP ASI baru diberikan pada bayi berusia 6 bulan yaitu ASI adalah satusatunya makanan dan minuman yang dibutuhkan oleh bayi sampai berumur 6 bulan, Menunda makanan padat sampai bayi berumur 6 bulan dapat menghindarkan dari berbagai risiko penyakit, Menunda pemberian makanan padat memberikan kesempatan pada sistem pencernaan bayi untuk berkembang menjadi lebih matang, menunda pemberian makanan padat membantu para ibu untuk menjaga kesediaan ASI.

\section{TidakRewel}

Menurut penelitian dokter astrid wulan kusumoastuti (2017) Penting untuk diketahui Pemberian MPASI pada anak harus dilakukan secara bertahap. Dimulai dari yang paling halus sampai dengan pengenalan makanan padat seperti nasi atau biskuit. Anak mulai diperkenalkan kepada MPASI memasuki bulan ke-7 (sudah genap 6 bulan). MPASI yang pertama kali diberikan umumnya disarankan bubur, bubur dari sumber-sumber karbohidrat maupun puree buah. Pada bulan pertama MPASI, targetnya adalah pengenalan rasa, sehingga menu yang disajikan ialah menu tunggal dalam 1 kali makan, misalnya bubur beras saja atau puree pepaya saja. Selain itu, karena ini masih tahap pengenalan, jangan heran kalau ada anak ketika masa pemberian MP ASI ada yang rewel, hal dapat terjadi bukan karena bayi tidak menyukai MP ASI yang kita berikan akan tetapi mungkin porsinya masih sangat sedikit atau jumlahnya sangat banyak, misalnya hanya sekitar 2-3 sendok teh orang dewasa. Pada tahap MPASI harus benar benar di pahami engan baik, gunakan aturan 4 hari yaitu mengenalkan 1 macam makanan baru selama 4 hari berturut-turut sebelum mengenalkan makanan baru lainnya. Tujuannya selain agar abayi mengetahui rasanya, juga untuk melihat apakah ada reaksi alergi terhadap makanan tersebut. Sebab dimasa ini adalah masa pealihan dari ASI ke MP ASI, Jadi untuk pemberian bubur karbohidrat di fase ini sangat rekomendasikan, selain halus untuk di cerna oleh bayi dan mudah juga untuk proses pembuatanya sehingga bayi atau ibu tida merasa kesulitan untuk mendapatkannya.

\section{KESIMPULAN}

Berdasarkanhasildanpembahasanpadapenelitia nini,

makadapatdisimpulkanbahwapemberiannasipapahbayi usi 6-12 bulan di desaSambori, KecematanMonta, KabupatenBimamenghasilkan 4 temayaitu 1) dayatahantubuhkuat 2) kuatmenahanlapar 3) cepatkenyang 4) tidakrewel.

\section{DAFTAR PUSTAKA}

1. Departemen Kesehatan, 2008. Laporan Nasional Riset Kesehatan Dasar 2007. ,Jakarta.

2. Dewey,K.G.,Cohen, R.J.,Brown K.H.,\&Rivera L.L (2001) Effects of Exclusive Breasfeeding for four versus sixt month on maternal nutritional status and infant motor development; Result of two month randomized trial in Honduras. Jurnal of Nutrition, 13 pp,262-267.

3. Fawzi WW, Herrera MG, Nestel P, el Amin A, Mohamed KA. A longitudinal study of prolonged breastfeeding in relation to child undernutrition. Int J Epidemiol 1998;27:255-60.

4. Foster.G.M, Andersen B.G, 1986. Antropologi Kesehatan. Penerbit Universitas Indonesia Graeff.J.A, Elder.J.P,Booth.E.M. 1996. Communication For Health And Behavior Change, Gadjah Mada University Press. 
5. Hediger ML, Overpeck MD, Ruan WJ, Troendle JF. Early infant feeding and growth status of USborn infants and children aged 4-71 mo: analyses from the third National Health and Nutrition Examination

6. Kotler,P.1997, Manajemen Pemasaran , Edisi Bahasa Indonesia, PT Prenhallindo, Jakarta. Kruger R, Gericke GJ. A qualitative exploration of rural feeding and weaning practices, knowledge and attitudes on nutrition. Public Health Nutr 2003;6:217-223

7. Rohmin, A., Malahayati, N., \& Hartati, H. (2016).Faktor-Faktor yang Mempengaruhi Praktik Pemberian Makanan Prelakteal pada
BayiBaru Lahir di Kecamatan Bukit Kecil KotaPalembang.Jurnal Kesehatan Survey, 19881994. Am J Clin Nutr 2000;72:159-67.

8. Rahayu sri, dkk. (2018). Aspek sosial budaya suku sasak tentangpemberian makan prelaktat padaBayi di wilayah kerja puskesmas lambale kabupaten buton utara tahun 2017. Jurnal ilmiah mahasiswa kesehatan masyarakat. Vol.3/no.1

9. Sulistyawati, Ari dan Nugraheny, Esti. 2013. Asuhan Kebidanan Pada Ibu Bersalin. Jakarta : Salemba Medika.

10. WHO, 'Diet, nutrition and prevention of chronic diseases: Report of the Joint WHO/FAO Expert Consultation’, Geneva, 2002. 